\title{
Lessons from a pandemic on practices versus products in agriculture
}

\author{
David R. Montgomery ${ }^{1} \cdot$ Anne Biklé $^{2}$
}

Accepted: 25 April 2020 / Published online: 13 May 2020

(c) Springer Nature B.V. 2020

Never in our lifetimes has the duality of the microbial world been so up close and personal. Thus far, one clear lesson of the current pandemic is that changing behavior-sheltering at home and social distancing-can quickly wield extraordinary power. Frequent hand washing, infrequent grocery shopping, and public mask wearing have become go-to practices for many people. In the Washington where we live, these rapidly adopted new behaviors and a stay-athome order issued early on helped reduce COVID-19 cases and deaths by mid April.

Products like liquid soaps and hand sanitizers enable us to practice good hygiene, while masks build on the practice of social distancing. Still, we all want the ultimate product-a vaccine. But we don't have one yet.

The case for practices is relevant in another way. Nearly half of all American adults suffer from two or more chronic health conditions, including high blood pressure, obesity, and Type 2 diabetes (CDC 2020). And in the context of COVID-19, we know that people with chronic disease(s) suffer more severe symptoms and have a higher death rate. This unsettling reality illustrates the value of practices that underpin good health. For during a pandemic, who wouldn't want their physical and mental health to be as fully functional and robust as possible?

Dietary practices, we now know, have a critical influence on the human microbiome, the communities of bacteria and other microbes living on and in our bodies. When a person includes an abundance of whole grains, fruits, and vegetables in their diet it spurs certain gut-dwelling microbiota (or a person's own cells) to make an array of chemical compounds, many of which help prevent the onset of chronic

This article is part of the Topical Collection: Agriculture, Food \& COVID-19.

David R. Montgomery

bigdirt@uw.edu

1 Department of Earth and Space Sciences, University of Washington, Seattle, USA

2 www.Dig2Grow.com, Seattle, USA diseases (Montgomery and Biklé 2016). It's like having an inner pharmacist to imbue one's immune, nervous, and circulatory systems with preventative medicine. While pharmaceutical products play an important role in treating chronic diseases, a better course of action is to greatly reduce the need for people to rely on them in the first place.

The pandemic also offers us the opportunity to reexamine how we use practices and products. Too often we put them at polar ends of a continuum. And while this can yield success at times, finding synergies between practices and products generally produces the best results.

Agriculture is ripe for such leveraging, especially in the area of restoring soil health to farmland. Implementing complementary practices and products will be a heavy lift given the degree to which livelihoods and businesses are embedded on the product end of the continuum.

Conventional agriculture today largely relies on chemical products to substitute for practices that create and sustain healthy, fertile soil. But substitutes rarely work as well as the real thing. The evidence? Despite the steady rise in fertilizer and pesticide use, these products have not solved the soil fertility and pest problems that plague farmers-they manage symptoms.

Managing the symptoms of biologically impaired soil, however, has put humanity in a dire situation. Standard input- and tillage-intensive farming has already degraded about a third of the world's farmland (Pimentel et al. 1995). And we remain on track to degrade another third of global farmland in the current century (UN FAO 2015).

We appear to be approaching the end of the line for intensifying agricultural production using agrochemical products. There simply is no vaccine to cure what ails agricultural soils. But there is significant untapped potential to move agriculture back toward the middle of the product-practice continuum.

In re-envisioning farming systems, we need to start with practices known to safeguard soil health. Past societies around the world once relied on specific farming practices adapted to local and regional conditions to build soil fertility and ensure healthy, disease- and pest-resistant crops. 
Tremendous opportunities exist to use these practices once again. Adopting a new system of integrated practices based on no-till planting, cover cropping, diverse crop rotations, and reintegrating livestock onto farms could replace degenerative conventional practices and greatly reduce the use of diesel, fertilizer, and pesticides (Montgomery 2017). To support regenerative practices we'll need new products like no-till planters and cover-crop rollers in a range of sizes to handle more types of crops on farms of all sizes, as well as microbial inoculants to accelerate the biological recovery of the soil microbiome. Deploying mutually supportive practices and products gives us the best chance of solving the intertwined problems around soil health, environmental quality, and human health.

Oddly enough, a key lesson from the ongoing viral plague sheds light on how to transform agriculture. For adopting regenerative practices can unleash rapid change through how we treat the land.

\section{References}

Centers for Disease Control and Prevention. 2020. About Chronic Diseases. https://www.cdc.gov/chronicdisease/about/index.htm. Accessed 24 April 2020.
Montgomery, D.R. 2017. Growing a Revolution: Bringing Our Soil Back to Life. New York: W.W. Norton.

Montgomery, D.R., and A. Biklé. 2016. The Hidden Half of Nature: The Microbial Roots of Life and Health. New York: W.W. Norton.

Pimentel, D., et al. 1995. Environmental and Economic Costs of Soil Erosion and Conservation Benefits. Science 267: 1117-1123.

UN Food and Agriculture Organization (UN FAO). 2015. Status of the World's Soil Resources, Technical Summary. In Intergovernmental Technical Panel on Soils, ed. L. Montanarella. Rome: Food and Agriculture Organization of the United Nations.

Publisher's Note Springer Nature remains neutral with regard to jurisdictional claims in published maps and institutional affiliations.

David R. Montgomery is professor of geomorphology at the University of Washington, and author most recently of Growing a Revolution: Bringing Our Soil Back to Life.

Anne Biklé is a science writer focusing on human health, microbiomes, and agriculture. She is also the co-author of The Hidden Half of Nature: The Microbial Roots of Life and Health. 